\title{
Kadar Hemoglobin (Hb) Ibu Hamil Pre Dan Post Pemberian Tablet Zat Besi (Fe) Di Uptd Puskesmas Kecamatan Sananwetan Kota Blitar
}

\author{
Hemoglobin's Concentration (Hb) Pregnant Mother Pre And Post Giving Iron Tablets (Fe) \\ In Primary Health Care Services Sananwetan Blitar
}

\author{
Sunarti ${ }^{1}$, Ellysa Eka Ratnasari ${ }^{2}$
}

1. Dosen Pengajar (Prodi D3 Keperawatan Blitar, Poltekes Kemenkes Malang,)*

2. Mahasiswa (Prodi D3 Keperawatan Blitar, Poltekes Kemenkes Malang)

*corresponding author: s.kepsunarti@yahoo.co.id

\begin{abstract}
Background: Anemia occurs due to a lack of iron intake $(\mathrm{Fe})$ in foods consumed by the marked hemoglobin $(\mathrm{Hb})$ rate below $11 \mathrm{~g} / \mathrm{dL}$. In district health Sananwetan Blitar implement the program of giving iron tablet $(\mathrm{Fe})$ to pregnant mother as one effort to increase hemoglobin $(\mathrm{Hb})$ as anemia prevention.

Purpose: The general purpose of this research is to know the change of hemoglobin $(\mathrm{Hb})$ rate of pregnant mother pre and post iron tablet $(\mathrm{Fe})$ in district health Sananwetan Blitar.

Method: The research method used is descriptive research. The population in this study were 76 with 31 samples of pregnant mother.

Results: The data were collected from 25 February to 31 March 2017. The result of this study was an abnormal hemoglobin $(\mathrm{Hb})$ rate of $74.2 \%$ (23 pregnant mother) before iron tablet $(\mathrm{Fe})$ and after iron tablet $(\mathrm{Fe}$ ) normal hemoglobin $(\mathrm{Hb})$ is $77.4 \%$ (24 pregnant mother). With an average increase in hemoglobin $(\mathrm{Hb})$ rate of pre and post pregnant mother is $1.1 \mathrm{~g} / \mathrm{dL}$.

Conclusion: Provision of iron tablets $(\mathrm{Fe})$ in pregnant mother can increase hemoglobin $(\mathrm{Hb})$. Provision of iron tablets can increase hemoglobin $(\mathrm{Hb})$ rate of pregnant mother. Recommendation for health personnel district health Sananwetan Blitar that is giving the right information to pregnant mother about the importance of iron tablet ( $\mathrm{Fe}$ ).
\end{abstract}

Keyword: Hemoglobin, Iron Tablet, Pregnant Mother

\section{ABSTRAK}

Latar Belakang: Anemia terjadi karena kurangnya asupan zat besi $(\mathrm{Fe})$ pada makanan yang dikonsumsi dengan ditandai nilai kadar hemoglobin $(\mathrm{Hb})$ dibawah $11 \mathrm{gr} / \mathrm{dL}$. Di UPTD Puskesmas Kecamatan Sananwetan menerapkan program pemberian tablet zat besi (Fe) pada ibu hamil sebagai salah satu upaya untuk menaikkan kadar hemoglobin ( $\mathrm{Hb}$ ) sebagai pencegahan anemia.

Tujuan: Tujuan umum dari penelitian ini adalah mengetahui perubahan kadar hemoglobin $(\mathrm{Hb})$ ibu hamil pre dan post pemberian tablet zat besi $(\mathrm{Fe})$ di UPTD Puskesmas Kecamatan Sananwetan. Metode: Metode penelitian yang digunakan penelitian deskriptif. Populasi dalam penelitian ini sejumlah 76 dengan 31 sampel ibu hamil. Waktu pengambilan data dilaksanakan pada 25 Februari sampai 31 Maret 2017.

Hasil: Hasil dari penelitian ini adalah kadar hemoglobin $(\mathrm{Hb})$ tidak normal sebanyak $74.2 \%$ (23 ibu hamil) sebelum pemberian tablet zat besi $(\mathrm{Fe})$ dan setelah pemberian tablet zat besi ( $\mathrm{Fe})$ kadar hemoglobin $(\mathrm{Hb})$ normal sebanyak $77.4 \%$ (24 ibu hamil). Dengan rata-rata kenaikan kadar hemoglobin $(\mathrm{Hb})$ ibu hamil pre dan post adalah sebesar $1.1 \mathrm{gr} / \mathrm{dL}$.

Kesimpulan: Pemberian tablet zat besi (Fe) pada ibu hamil dapat meningkatkan kadar hemoglobin $(\mathrm{Hb})$. Pemberian tablet zat besi dapat meningkatkan kadar hemoglobin ( $\mathrm{Hb}$ ) pada ibu hamil. Rekomendasi untuk petugas kesehatan UPTD Puskesmas Kecamatan Sananwetan yaitu pemberian informasi yang tepat kepada ibu hamil mengenai pentingnya tablet zat besi $(\mathrm{Fe})$.

Kata kunci: Hemoglobin, Tablet Zat Besi, Ibu hamil 


\section{PENDAHULUAN}

Kematian ibu adalah kematian seorang wanita yang terjadi selama kehamilan sampai dengan 42 hari setelah berakhirnya kehamilan, tanpa memerhatikan lama dan tempat terjadinya kehamilan, yang disebabkan oleh atau dipicu oleh kehamilannya atau penanganan kehamilannya, tetapi bukan karena kecelakaan (Syafrudin \& Hamidah, 2009). Angka kematian ibu (AKI) merupakan salah satu indikator keberhasilan pembangunan daerah dan juga digunakan sebagai penentu indeks pembangunan manusia. Maka dari itu, kesehatan ibu menjadi salah satu dari delapan target utama dalam tujuan pembangunan Millennium Development Goals (MDGs). Setiap tahun sekitar 20.000 perempuan di Indonesia meninggal akibat komplikasi dalam persalinan (undp,2016). Berdasarkan data Dinas Kesehatan Provinsi Jawa Timur mencatat, pada tahun 2015 kematian ibu mencapai 121 kematian per tahun (Depkes 2016). Sedangkan Dinas Kesehatan Kota Blitar mencatat pada tahun 2015 hanya satu orang ibu yang meninggal (Dinkes blitar, 2016).

Penyebab kematian ibu ada secara langsung dan tidak langsung. Secara langsung berupa perdarahan, infeksi dan keracunan kehamilan, sedangkan secara tidak langsung diantaranya kehamilan dengan anemia (Manuaba, 2010). Salah satu upaya dalam menurunkan tingkat kematian ibu adalah meningkatkan status kesehatan seperti terpenuhinya asupan gizi pada ibu hamil sampai bersalin, misalnya kebutuhan akan zat besi selama kehamilan. Zat besi merupakan salah satu mineral yang berguna mengantarkan oksigen ke seluruh tubuh dan janin, mengantarkan sari pati makanan dalam tubuh, sebagai pembentuk energi dan mengurangi risiko anemia. Anemia gizi terjadi karena kurangnya asupan zat besi pada makanan yang dikonsumsi setiap hari yang ditandai dengan kadar hemoglobin $(\mathrm{Hb})$ di bawah normal. Anemia sering ditandai dengan penurunan jumlah sel darah merah dan konsentrasi $\mathrm{Hb}$ dibawah normal (Green \& Judith, 3 2012). Hemoglobin ( $\mathrm{Hb}$ ) merupakan zat warna yang terdapat dalam darah merah yang berguna untuk mengangkut oksigen dan $\mathrm{CO}_{2}$ dalam tubuh (Adriani \& Wirjatmadi, 2012). Pada wanita tidak hamil dikatakan anemia jika kadar hemoglobin (Hb) kurang dari 12 $\mathrm{g} / \mathrm{dl}$ dan pada wanita hamil kurang dari $11 \mathrm{~g} / \mathrm{dl}$.

Menurut Peraturan Menteri Kesehatan RI Nomor 88 Tahun 2014 pemberian tablet tambah darah kepada wanita usia subur (WUS) dan ibu hamil merupakan salah satu upaya penting dalam mencegah dan menanggulangi anemia akibat kekurangan zat besi dan asam folat. Bagi ibu hamil diberikan minimal 90 tablet selama kehamilannya. Pada Riskesdas 2013 didapatkan konsumsi zat besi dan variasi jumlah asupan zat besi selama hamil di Indonesia sebesar $89.1 \%$. Diantara yang mengonsumsi zat besi tersebut, terdapat $33.3 \%$ mengonsumsi 
minimal 90 hari selama kehamilan. Adapun penyebab tersering anemia pada kehamilan adalah anemia defisiensi zat besi dan kehilangan darah akut (Cunningham dkk, 2012).

Kurangnya pengetahuan ibu hamil terhadap pentingnya pelayanan kesehatan ibu hamil, menjadi faktor meningkatnya angka kematian ibu di Indonesia. Beberapa diantaranya yaitu tablet zat besi yang diberikan tidak dikonsumsi secara rutin dan ibu hamil kurang peduli terhadap kadar hemoglobinnya dengan tidak melakukan pemeriksaan kadar hemoglobin $(\mathrm{Hb})$ sesuai program. Hal ini mengakibatkan kadar hemoglobin $(\mathrm{Hb})$ tidak dapat teridentifikasi untuk penatalaksanaan lebih lanjut.

Data dari hasil laporan UPTD Puskesmas se Kota Blitar diperoleh dari 80 ibu hamil baru pada bulan November sebanyak 52 ibu hamil (65\%) memiliki kadar hemoglobin ( $\mathrm{Hb})$ rendah dibawah $11 \mathrm{~g} / \mathrm{dl}$ dengan jumlah hemoglobin $(\mathrm{Hb})$ rata-rata $10 \mathrm{~g} / \mathrm{dl}$. Di UPTD Puskesmas Kecamatan Sananwetan ibu dengan kadar hemoglobin $(\mathrm{Hb})$ rendah sebanyak 35 ibu hamil (67.3\%), di UPTD Puskesmas Kecamatan Sukorejo sebanyak 4 ibu hamil (7.6\%) dengan kadar hemoglobin $(\mathrm{Hb})$ rendah, sedangkan di UPTD Puskesmas Kecamatan Kepanjen Kidul 13 ibu hamil $(25 \%)$ dengan kadar hemoglobin $(\mathrm{Hb})$ rendah.

Berdasarkan studi pendahuluan yang dilakukan peneliti pada tanggal 27-30 September 2016 kepada $10 \mathrm{ibu}$ hamil di UPTD Puskesmas Kecamatan Sananwetan, 6 dari 10 responden menyatakan bahwa mereka tidak rutin mengonsumsi tablet zat besi dengan alasan lupa, bau tidak enak, merasa mual, dan muntah. Dan menurut pengamatan dari peneliti untuk evaluasi setelah program pemberian tablet zat besi pada ibu hamil belum berjalan maksimal, sehingga belum diketahui secara pasti keberhasilan program pemberian tablet zat besi tersebut berjalan.

Berdasarkan uraian-uraian di atas, penulis tertarik untuk meneliti tentang "Kadar Hemoglobin ( $\mathrm{Hb}$ ) pada Ibu Hamil Pre dan Post Pemberian Tablet Zat Besi (Fe) di UPTD Puskesmas Kecamatan Sananwetan Kota Blitar".

\section{METODE}

Penelitian ini menggunakan desain penelitian deskriptif. Populasi penelitian adalah ibu hamil di UPTD Puskesmas Kecamatan Sananwetan Kota Blitar, besar sampel sebanyak 31 ibu hamil dengan teknik purposive sampling. Pengumpulan data dilakukan dengan pengisian kuesioner dan pemeriksaan kadar hemoglobin $(\mathrm{Hb})$ menggunakan metode $\mathrm{Hb}$ Meter (Pocket) / Easy Touch GCHb Tipe : ET - 321, yang dilakukan di Poli KIA UPTD Puskesmas Kecamatan Sananwetan Kota Blitar, Pustu Klampok, Pustu Plosokerep, dan rumah responden yang berada di wilayah Kecamatan Sananwetan pada 25 Februari - 31 Maret 2017. Analisa data secara deskriptif dengan tampilan prosentase. 


\section{HASIL}

Secara umum, kadar hemoglobin $(\mathrm{Hb})$ pada ibu hamil pre dan post pemberian talet zat besi (Fe) di UPTD Puskesmas Kecamatan Sananwetan Kota Blitar. Data Umum Data Umum Kadar Hemoglobin (Hb) Pada Ibu Hamil Pre dan Post Pemberian Tablet Zat Besi (Fe) di UPTD Puskesmas Sananwetan Kota Blitar dapat dilihat pada tabel 1. Data kadar hemoglobin (Hb) ibu hamil pre pemberian tablet zat besi (Fe) di UPTD Puskesmas Kecamatan Sananwetan dapat dilihat pada tabel 2. Data kadar hemoglobin ( $\mathrm{Hb})$ ibu hamil post pemberian tablet zat besi (Fe) di UPTD Puskesmas Kecamatan Sananwetan dapat dilihat pada tabel 3. Data perubahan kadar hemoglobin $(\mathrm{Hb})$ ibu hamil pre dan post pemberian tablet zat besi (Fe) di UPTD Puskesmas Kecamatan Sananwetan dapat dilihat pada tabel 4. Data perubahan kategori kadar hemoglobin $(\mathrm{Hb})$ ibu hamil pre dan post pemberian tablet zat besi (Fe) di UPTD Puskesmas Kecamatan Sananwetan dapat dilihat pada tabel 5. Grafik rata-rata perubahan kadar hemoglobin (Hb) ibu hamil pre dan post pemberian tablet zat besi (Fe) di UPTD Puskesmas Kecamatan Sananwetan dapat dilihat pada gambar 1 .

\section{PEMBAHASAN}

Dari hasil penelitian terhadap 31 ibu hamil didapatkan kadar hemoglobin $(\mathrm{Hb})$ tidak normal sebanyak 74.2\% (23 ibu hamil) dan kadar hemoglobin (Hb) normal sebanyak 25.8\% (8 ibu hamil) sebelum pemberian tablet zat besi ( $\mathrm{Fe})$. Setelah diberi perlakuan dengan pemberian tablet zat besi (Fe) selama 90 hari pemberian, maka diperoleh hasil bahwa kadar hemoglobin $(\mathrm{Hb})$ tidak normal pada ibu hamil sebanyak 22.6\% (7 ibu hamil) dan kadar hemoglobin $(\mathrm{Hb})$ normal sebanyak 77.4\% (24 ibu hamil). Sebanyak 87.1\% (27 ibu hamil) mengalami kenaikan kadar hemoglobin $(\mathrm{Hb})$ dan terjadi penurunan kadar hemoglobin $(\mathrm{Hb})$ sebanyak $12.9 \%$ (4 ibu hamil). Pada penelitian ini diketahui juga lebih dari setengah ibu hamil mengalami perubahan kategori dari tidak normal menjadi normal 54.8\% (17 ibu hamil), sebanyak 19.4\% (6 ibu hamil) tidak mengalami perubahan kadar hemoglobin $(\mathrm{Hb})$ yang berarti tetap tidak normal, sebanyak 22.6\% (7 ibu hamil) memiliki kadar hemoglobin ( $\mathrm{Hb}$ ) tetap normal, dan sebanyak 3.2\% (1 ibu hamil) mengalami perubahan kadar hemoglobin $(\mathrm{Hb})$ dari normal menjadi tidak normal.

Tablet zat besi adalah tablet tambah darah yang berisi zat besi folat yang berbentuk tablet. Tiap tablet mengandung $200 \mathrm{mg}$ sulfat ferosus (yang setara dengan $60 \mathrm{mg}$ besi elemental) dan $0.25 \mathrm{mg}$ asam folat (Depkes RI, 2005). Pemberian tablet zat besi (Fe) pada saat kehamilan merupakan salah satu cara untuk meningkatkan kadar hemoglobin $(\mathrm{Hb})$ dan untuk mengurangi terjadinya risiko anemia pada ibu hamil. Pemberian preparat tablet zat besi (Fe) 
$60 \mathrm{mg}$ besi/hari dapat menaikkan kadar hemoglobin $(\mathrm{Hb})$ sebanyak $1 \mathrm{gr} / \mathrm{dL}$ perbulan (Saifuddin, 2002). Hemoglobin (Hb) merupakan zat warna yang terdapat dalam darah merah yang berguna untuk mengangkut oksigen dan $\mathrm{CO}_{2}$ dalam tubuh (Adriani \& Wirjatmadi, 2012).

Menurut pendapat peneliti, pemberian tablet zat besi (Fe) pada ibu hamil dapat meningkatkan kadar hemoglobin ( $\mathrm{Hb})$. Hal ini sangat wajar jika terjadi perubahan kadar hemoglobin $(\mathrm{Hb})$ ibu hamil dari yang tidak normal menjadi normal, karena ibu hamil telah diberi perlakuan dengan pemberian tablet zat besi (Fe), dan jika terjadi perubahan dari kategori normal menjadi tidak normal kemungkinan hal ini disebabkan oleh adanya faktor tambahan selain dari faktor makanan misalnya penyakit penyerta seperti hipertensi dan diabetes militus pada ibu hamil yang dapat menghambat metabolisme zat besi (Fe) sehingga zat besi (Fe) yang sudah masuk ke dalam tubuh tidak diserap secara maksimal. Dan juga selama masa kehamilan terjadi perubahan fisiologi kehamilan pada sistem sirkulasi dan kardiovaskuler dimana volume plasma bertambah lebih cepat pada awal kehamilan kemudian secara perlahan sampai akhir kehamilan yang mengakibatkan terjadinya perubahan kadar hemoglobin ( $\mathrm{Hb})$ dalam darah. Oleh karena itu, sangat penting memberikan asupan besi sejak masa prenatal supaya cadangan besi pada saat hamil cukup memadai.

Berikut akan dijabarkan pembahasan tentang kadar hemoglobin $(\mathrm{Hb})$ ibu hamil pre dan post pemberian tablet zat besi $(\mathrm{Fe})$ serta perubahan kadar hemoglobin $(\mathrm{Hb})$ pada ibu hamil pre dan post pemberian tablet zat besi (Fe) di UPTD Puskemas Kecamatan Sananwetan.

\section{Kadar hemoglobin ( $\mathrm{Hb})$ ibu hamil pre pemberian tablet zat besi (Fe)}

Berdasarkan hasil penelitian kepada 31 ibu hamil didapatkan lebih dari setengah kadar hemoglobin $(\mathrm{Hb})$ ibu hamil tidak normal yaitu sebanyak 74.2\% (23 ibu hamil) dan kadar hemoglobin ( $\mathrm{Hb}$ ) normal sebanyak 25.8\% (8 ibu hamil) sebelum pemberian tablet zat besi (Fe). Hasil tabulasi silang antara seluruh ibu hamil 100\% (31 ibu hamil) memiliki kebiasaan makan 3 - 4 kali yang belum mengonsumsi tablet zat besi $(\mathrm{Fe})$ memiliki kadar hemoglobin $(\mathrm{Hb})$ tidak normal yaitu sebanyak 74.2\% (23 ibu hamil) dan kadar hemoglobin ( $\mathrm{Hb}$ ) normal hanya $25.8 \%$ (8 ibu hamil).

Kadar hemoglobin $(\mathrm{Hb})$ pre adalah kadar hemoglobin awal ibu hamil pada saat pertama kali memeriksakan kehamilannya. Kadar hemoglobin $(\mathrm{Hb})$ pre tidak selalu memiliki nilai rendah atau tidak normal. Nilai hemoglobin $(\mathrm{Hb})$ pre ini dapat dipengaruhi oleh beberapa faktor diantaranya pola makan, usia, tempat tinggal, dan jenis kegiatan. Kadar hemoglobin ( $\mathrm{Hb}$ ) pre pemberian tablet zat besi pada ibu hamil adalah kadar hemoglobin $(\mathrm{Hb})$ pada ibu hamil sebelum diberikan perlakuan pemberian tablet zat besi (Fe) selama 90 hari. 
Zat besi (Fe) merupakan unsur yang penting untuk pembentukan hemoglobin $(\mathrm{Hb})$, berfungsi mengantarkan oksigen ke seluruh tubuh dan janin, mengantarkan sari pati makanan dalam tubuh, sebagai pembentuk energi dan mengurangi risiko anemia. Pada masa kehamilan terjadi beberapa perubahan fisiologi kehamilan, salah satu diantarannya adalah perubahan metabolisme ibu hamil. Basal metabolisme rate meningkat sampai 15 - 20\% sehingga kebutuhan karbohidrat, protein, kadar kolestrol plasma meningkat dan juga kebutuhan akan kalsium, fosfor, magnesium, dan zat besi (Fe) (Adriani \& Wirjatmadi, 2012).

Kebutuhan tablet Fe pada wanita hamil yaitu rata-rata mendekati 800 mg. Kebutuhan ini terdiri dari, sekitar $300 \mathrm{mg}$ diperlukan untuk janin dan plasenta serta $500 \mathrm{mg}$ lagi digunakan untuk meningkatkan massa haemoglobin maternal. Kurang lebih $200 \mathrm{mg}$ lebih akan dieksresikan lewat usus, urin dan kulit. Makanan ibu hamil setiap 100 kalori akan menghasilkan sekitar 810 mg tablet Fe. Perhitungan makan 3 kali dengan 2500 kalori akan menghasilkan sekitar 20$25 \mathrm{mg}$ tablet Fe perhari. Selama kehamilan dengan perhitungan 288 hari, ibu hamil akan menghasilkan tablet Fe sebanyak 100 mg sehingga kebutuhan tablet Fe masih kekurangan untuk wanita hamil (Rukiah dkk, 2009). Selama masa kehamilan dengan perhitungan 288 hari, ibu hamil akan menghasilkan zat besi (Fe) sebanyak $100 \mathrm{mg}$ sehingga kebutuhan zat besi (Fe) masih kurang untuk ibu hamil (Manuaba, 2008).

Menurut pendapat peneliti, jika kadar hemoglobin $(\mathrm{Hb})$ pre atau kadar hemoglobin $(\mathrm{Hb})$ ibu hamil bernilai rendah dikarenakan ketika hamil kebutuhan zat besi (Fe) meningkat dan zat besi (Fe) tidak dapat dipenuhi hanya dari makanan saja sehingga ibu hamil harus mengonsumsi suplemen zat besi $(\mathrm{Fe})$ tambahan untuk memenuhi kebutuhan akan zat besi $(\mathrm{Fe})$ agar terhindar dari terjadinya komplikasi dalam kehamilan salah satunya anemia gizi besi.Sesuai dengan program pemerintah setiap ibu hamil wajib megonsumsi tablet zat besi minimal 90 hari selama masa kehamilan agar terhindar dari terjadinya risiko anemia. Pada penelitian ini tidak hanya ibu hamil yang memiliki kadar hemoglobin $(\mathrm{Hb})$ tidak normal 74.2\% (23 ibu hamil) yang mengikuti program pemberian tablet zat besi (Fe) tetapi ibu hamil yang memiliki kadar hemoglobin $(\mathrm{Hb})$ normal 25.8\% (8 ibu hamil) juga mengikuti program pemberian tablet zat besi $(\mathrm{Fe})$. Selama masa kehamilan zat besi $(\mathrm{Fe})$ diperlukan untuk memproduksi hemoglobin $(\mathrm{Hb})$ karena volume darah meningkat 50\%, sehingga hemoglobin $(\mathrm{Hb})$ dan konstituen darah lainnya juga meningkat (Simkin, Whalley, \& Keppler, 2007). Dalam masa kehamilan kebutuhan zat-zat gizi meningkat. Hal ini diperlukan untuk memenuhi kebutuhan tumbuh kembang janin, pemeliharaan kesehatan ibu, dan persediaan laktasi baik untuk ibu maupun janin. 
Menurut pendapat peneliti, pemberian zat besi $(\mathrm{Fe})$ tambahan merupakan salah satu upaya penting untuk memenuhi kebutuhan zat besi (Fe) pada ibu hamil dengan pemberian tablet zat besi $(\mathrm{Fe})$ pada semua ibu hamil, walaupun ibu hamil memiliki kadar hemoglobin $(\mathrm{Hb})$ normal sebelum pemberian tablet zat besi (Fe) hal ini dikarenakan tingginya kebutuhan zat besi (Fe) sebagai pembentuk hemoglobin $(\mathrm{Hb})$ pada masa kehamilan. Pemberian tablet zat besi $(\mathrm{Fe})$ ini bertujuan untuk meningkatkan kadar hemoglobin $(\mathrm{Hb})$ pada ibu hamil sampai tahap normal, mencegah terjadinya anemia, dan menjaga pertumbuhan janin secara optimal.

\section{Kadar hemoglobin (Hb) ibu hamil post pemberian tablet zat besi (Fe)}

Berdasarkan hasil penelitian kepada 31 ibu hamil setelah diberikan perlakuan dengan pemberian tablet zat besi (Fe) selama 90 hari pemberian, maka diperoleh hasil bahwa kadar hemoglobin $(\mathrm{Hb})$ tidak normal sebanyak 22.6\% (7 ibu hamil) dan kadar hemoglobin $(\mathrm{Hb})$ normal sebanyak 77.4\% (24 ibu hamil). Dan diketahui juga frekuensi konsumsi tablet zat besi (Fe) bahwa seluruh ibu hamil yaitu sebanyak 100\% (31 ibu hamil) mengonsumsi tablet zat besi dalam satu hari sekali. Hasil tabulasi silang antara kadar hemogobin $(\mathrm{Hb})$ post pemberian tablet zat besi (Fe) dengan frekuensi konsumsi tablet zat besi (Fe) yang diminum sekali sehari sebanyak 77.4\% (24 ibu hamil) memiliki kadar hemoglobin $(\mathrm{Hb})$ normal dan kadar hemoglobin ( $\mathrm{Hb}$ ) tidak normal sebanyak $22.6 \%$ (7 ibu hamil).

Kadar hemoglobin $(\mathrm{Hb})$ post adalah kadar hemoglobin $(\mathrm{Hb})$ akhir pada ibu hamil setelah diberi perlakuan. Kadar hemoglobin $(\mathrm{Hb})$ post pada ibu hamil salah satunya dapat di pengaruhi oleh pemberian tablet zat besi $(\mathrm{Fe})$. Penelitian ini sejalan dengan program pemerintah yang tertuang pada Peraturan Menteri Kesehatan RI Nomor 88 Tahun 2014 jika seseorang mengalami kekurangan zat besi (Fe) khususnya ibu hamil pemberian tablet zat besi (Fe) merupakan salah satu upaya penting dalam mencegah dan menanggulangi kekurangan zat besi (Fe). Pemberian preparat tablet zat besi (Fe) $60 \mathrm{mg}$ besi/hari dapat menaikkan kadar hemoglobin (Hb) sebanyak $1 \mathrm{gr} / \mathrm{dL}$ perbulan (Saifuddin, 2002). Sesuai dengan teori diharapkan kadar hemoglobin $(\mathrm{Hb})$ dapat normal pada ibu hamil yang mengonsumsi tablet zat besi (Fe), karena kebutuhan zat besi $(\mathrm{Fe})$ pada ibu hamil tidak dapat dipenuhi hanya dari makanan saja, walaupun makanan yang dimakan mengandung zat besi (Fe) dengan jumlah banyak dan absorpsinya tinggi. Karena itu pemenuhan kecukupan zat gizi dianjurkan dipenuhi melalui suplementasi.

Menurut pendapat peneliti, konsumsi tablet zat besi (Fe) pada awal masa kehamilan dengan ibu hamil yang memiliki kadar hemoglobin $(\mathrm{Hb})$ rendah merupakan salah satu upaya yang sangat penting guna menaikkan kadar hemoglobin $(\mathrm{Hb})$ dalam rentang normal karena 
dilihat dari pentingnya peran hemoglobin $(\mathrm{Hb})$ sebagai pengangkut oksigen dan $\mathrm{CO}_{2}$ dalam darah serta sebagai indikator terjadinya anemia. Jadi, pemberian tablet zat besi (Fe) sangat berpengaruh positif terhadap kadar hemoglobin ( $\mathrm{Hb})$ ibu hamil.

Untuk memenuhi serangkaian perubahan metabolisme yang terjadi pada ibu hamil terutama perubahan metabolisme zat besi (Fe) maka dibutuhkan beberapa sumber zat besi (Fe) sebagai pembentuk hemoglobin $(\mathrm{Hb})$. Untuk memenuhi kebutuhan guna pembentukan hemoglobin $(\mathrm{Hb})$ sebagian besar zat besi $(\mathrm{Fe})$ yang berasal dari pemecahan sel darah merah akan dimanfaatkan kembali baru kekurangannya harus dipenuhi dan diperoleh melalui makanan. Taraf gizi besi bagi seseorang sangat dipengaruhi oleh jumlah konsumsinya melalui makanan, bagian yang diserap melalui saluran pencernaan, cadangan zat besi (Fe) dalam jaringan, ekskresi dan kebutuhan tubuh (Adriani \& Wirjatmadi, 2012). Sumber baik zat besi (Fe) atau makanan yang tinggi akan zat besi (Fe) meliputi jeroan, daging, ikan, kuning telur, gandum, sereal, sayuran berdaun hijau tua dan beberapa jenis buah (Walsh, 2007).

Pada penelitian ini diketahui kadar hemoglobin $(\mathrm{Hb})$ tidak normal sebanyak $22.6 \%$ (7 ibu hamil), menurut peneliti hal ini disebabkan karena kurang terpenuhinya asupan nutrisi pendukung dari makanan yang dikonsumsi ibu hamil misalnya konsumsi sayur dan lauk pauk yang mengandung zat besi (Fe) dikonsumsi kadang-kadang oleh ibu hamil sehingga kebutuhan tidak terpenuhi. Adanya reaksi yang timbul setelah konsumsi tablet zat besi (Fe) misalnya mual dan muntah juga sebagai salah satu pemicu ibu hamil malas untuk mengonsumsi tablet zat besi (Fe) sebagai suplemen tambahan sehingga kebutuhan zat besi $(\mathrm{Fe})$ dalam tubuh belum terpenuhi.

\section{Perubahan kadar hemoglobin (Hb) ibu hamil pre dan post pemberian tablet zat besi} (Fe)

Berdasarkan hasil penelitian diketahui bahwa perubahan kadar hemoglobin $(\mathrm{Hb})$ setelah pemberian tablet zat besi $(\mathrm{Fe})$ pada ibu hamil yaitu kadar hemoglobin $(\mathrm{Hb})$ mengalami kenaikan yaitu sebanyak $87.1 \%$ (27 ibu hamil) dan terjadi penurunan sebanyak 12.9\% (4 ibu hamil). Dengan rata-rata kadar hemoglobin $(\mathrm{Hb})$ ibu hamil adalah dari $10.3 \mathrm{gr} / \mathrm{dL}$ kadar hemoglobin $(\mathrm{Hb})$ pre mengalami kenaikan menjadi $11.4 \mathrm{gr} / \mathrm{dL}$ kadar hemoglobin $(\mathrm{Hb})$ post pemberian tablet zat besi (Fe). Diketahui juga frekuensi konsumsi tablet zat besi (Fe) bahwa seluruh ibu hamil yaitu sebanyak 100\% (31 ibu hamil) mengonsumsi tablet zat besi (Fe) dalam satu hari sekali. Hasil dari tabulasi silang antara perubahan kadar hemoglobin $(\mathrm{Hb})$ pre dan post pemberian tablet zat besi ( Fe) dengan frekuensi konsumsi tablet zat besi (Fe) pada ibu hamil bahwa terjadi kenaikan sebanyak $87.1 \%$ (27 ibu hamil). 
Perubahan kadar hemoglobin $(\mathrm{Hb})$ adalah perubahan nilai kadar hemoglobin $(\mathrm{Hb})$ dari yang semula tidak normal menjadi normal atau sebaliknya. Perubahan kadar hemoglobin $(\mathrm{Hb})$ ini dilihat dari kadar hemoglobin $(\mathrm{Hb})$ awal dan akhir. Perubahan kadar hemoglobin $(\mathrm{Hb})$ pada ibu hamil antara pre dan post pemberian tablet zat besi terjadi karena adanya perlakuan dengan pemberian tablet zat besi $(\mathrm{Fe})$ selama 90 hari masa pemberian sesuai dengan program pemerintah. Pemberian tablet zat besi $(\mathrm{Fe})$ bertujuan untuk menaikkan kadar hemoglobin $(\mathrm{Hb})$ rendah pada ibu hamil sebagai salah satu upaya mempersiapkan persalinan pada ibu hamil.

Menurut pendapat peneliti, dengan pemberian tablet zat besi $(\mathrm{Fe})$ pada ibu hamil dapat menaikkan kadar hemoglobin $(\mathrm{Hb})$ akan tetapi harus disertai pola konsumsi makanan yang mengandung nutrisi khususnya makanan yang mengandung zat besi agar terpenuhinya cakupan zat besi (Fe) dalam tubuh ibu hamil. Pada ibu hamil zat besi (Fe) sangat dibutuhkan untuk mencegah terjadinya anemia dan menjaga pertumbuhan janin secara optimal. Pada penelitian ini terjadi kenaikan kadar hemoglobin $(\mathrm{Hb})$ antara pre dan post pemberian tablet zat besi $(\mathrm{Fe})$ sebesar $1.1 \mathrm{gr} / \mathrm{dL}$ hal ini menunjukkan bahwa program pemberian tablet zat besi (Fe) oleh pemerintah memberikan dampak positif terhadap perubahan kadar hemoglobin $(\mathrm{Hb})$ ibu hamil sehingga mengurangi terjadinya risiko anemia.

Besi merupakan unsur runutan (trace element) terpenting bagi manusia. Besi dengan konsentrasi tinggi terdapat dalam sel darah merah, yaitu sebagai bagian dari molekul hemoglobin $(\mathrm{Hb})$ yang mengangkut paru-paru. Hemoglobin $(\mathrm{Hb})$ akan mengangkut oksigen ke sel-sel yang membutuhkannya untuk metabolisme glukosa, lemak, dan protein menjadi energi (ATP). Menurut Estridge et al (2000) segala aktivitas tubuh baik secara fisik maupun psikis memerlukan energi, yang diperoleh dari proses metabolisme.

Pada penelitian ini terjadi penurunan kadar hemoglobin $(\mathrm{Hb})$ pada ibu hamil sebanyak $12.9 \%$ (4 ibu hamil). Menurut pendapat, peneliti hal ini terjadi karena adanya faktor penyebab lain selain dari makanan yang dikonsumsi oleh ibu hamil salah satu diantaranya adalah jenis kegiatan atau pekerjaan ibu hamil yang dapat menghambat metabolisme besi dalam tubuh sehingga tidak berjalan dengan baik hal ini terjadi karena kurangnya waktu istirahat ibu hamil, misalnya ibu hamil bekerja sebagai seorang pedagang di pasar yang harus bangun dini hari sehingga waktu istirahat nya kurang. Dan kemungkinan juga dapat dipengaruhi oleh pola konsumsi susu hamil yang berguna sebagai penunjang kebutuhan nutrisi selama masa kehamilan, sebagian besar susu hamil mengandung asam folat, vitamin $\mathrm{C}$, dan zat besi (Fe) sehingga konsumsi susu sangat dianjurkan guna memenuhi kebutuhan nutrisi terutama zat besi $(\mathrm{Fe})$ selama masa kehamilan. 


\section{KESIMPULAN}

Dari hasil penelitian terhadap 31 ibu hamil didapatkan kadar hemoglobin $(\mathrm{Hb})$ tidak normal sebanyak 74.2\% (23 ibu hamil) dan kadar hemoglobin ( $\mathrm{Hb}$ ) normal sebanyak $25.8 \%$ (8 ibu hamil) sebelum pemberian tablet zat besi ( $\mathrm{Fe})$. Setelah diberi perlakuan dengan pemberian tablet zat besi (Fe) selama 90 hari pemberian, maka diperoleh hasil bahwa kadar hemoglobin (Hb) tidak normal pada ibu hamil sebanyak 22.6\% (7 ibu hamil) dan kadar hemoglobin ( $\mathrm{Hb})$ normal sebanyak 77.4\% (24 ibu hamil). Sebanyak 87.1\% (27 ibu hamil) mengalami kenaikan kadar hemoglobin $(\mathrm{Hb})$ dan terjadi penurunan kadar hemoglobin $(\mathrm{Hb})$ sebanyak $12.9 \%$ (4 ibu hamil). Dengan rata-rata kadar hemoglobin $(\mathrm{Hb})$ ibu hamil adalah dari $10.3 \mathrm{gr} / \mathrm{dL}$ kadar hemoglobin $(\mathrm{Hb})$ pre mengalami kenaikan menjadi $11.4 \mathrm{gr} / \mathrm{dL}$ kadar hemoglobin $(\mathrm{Hb})$ post pemberian tablet zat besi (Fe). Pada penelitian ini diketahui juga lebih dari setengah ibu hamil mengalami perubahan kategori dari tidak normal menjadi normal 54.8\% (17 ibu hamil), sebanyak 19.4\% (6 ibu hamil) tidak mengalami perubahan kadar hemoglobin ( $\mathrm{Hb}$ ) yang berarti tetap tidak normal, sebanyak 22.6\% (7 ibu hamil) memiliki kadar hemoglobin $(\mathrm{Hb})$ tetap normal, dan sebanyak 3.2\% (1 ibu hamil) mengalami perubahan kadar hemoglobin ( $\mathrm{Hb}$ ) dari normal menjadi tidak normal. Terjadinya kenaikan dan penurunan kadar hemoglobin ( $\mathrm{Hb})$ pada ibu hamil ini disebabkan oleh berbagai faktor diantaranya adalah makanan, usia, dan jenis kelamin, tempat tinggal, dan jenis kegiatan. Pada penelitian ini terjadi kenaikan kadar hemoglobin $(\mathrm{Hb})$ antara pre dan post pemberian tablet zat besi $(\mathrm{Fe})$ sebesar $1.1 \mathrm{gr} / \mathrm{dL}$ hal ini menunjukkan bahwa program pemberian tablet zat besi $(\mathrm{Fe})$ oleh pemerintah memberikan dampak positif terhadap perubahan kadar hemoglobin $(\mathrm{Hb})$ ibu hamil sehingga sangat penting memberikan asupan besi sejak masa prenatal pada ibu hamil.

\section{SARAN}

\section{Kepada Institusi Pelayanan Kesehatan}

Kadar hemoglobin $(\mathrm{Hb})$ pada ibu hamil setelah diberikan perlakuan pemberian tablet zat besi $(\mathrm{Fe})$ adalah mengalami kenaikan hal ini sesuai dengan teori yang ada. Akan tetapi masih ada beberapa ibu hamil yang memiliki kadar hemoglobin $(\mathrm{Hb})$ rendah walaupun sudah diberikan tablet zat besi (Fe), maka masih ada faktor lain yang menyebabkan rendahnya kadar hemoglobin $(\mathrm{Hb})$. Sehingga pemberian informasi yang tepat kepada ibu hamil mengenai pentingnya program pemberian tablet zat besi $(\mathrm{Fe})$ harus lebih di tingkatkan agar hasil yang dicapai maksimal.

\section{Kepada Peneliti Lain}

Hasil penelitian ini dapat dijadikan dasar untuk melakukan penelitian lebih lanjut tentang faktor yang mempengaruhi rendahnya kadar hemoglobin $(\mathrm{Hb})$ pada ibu hamil. 


\section{Bagi Institusi Program Studi Keperawatan Blitar}

Hasil penelitian ini dapat bermanfaat dan dapat digunakan sebagai bahan bacaan dan masukan untuk keterlibatan mahasiswa dalam memberikan pengetahuan kadar hemoglobin (Hb) pada ibu hamil dan pentingnya zat besi $(\mathrm{Fe})$ di masyarakat.

\section{DAFTAR PUSTAKA}

Adriani, M., \& Wirjatmadi, B. 2012. Pengantar Gizi Masyarakat. Jakarta: Kencana Prenada Media Group.

Adriani, M., \& Wirjatmadi, B. 2012. Peranan Gizi dalam Siklus Kehidupan. Jakarta: Kencana Prenada Media Grup.

Arikunto, S. 2010. Prosedur Penelitian Suatu Pendekatan Praktik. Jakarta: Rineka Cipta.

Cunningham, F.G., Leveno., Bloom., Hauth., Rouse., \& Spong. (2012).

Obstetri illiams. Ed : 23, Vol 2. Jakarta : EGC.

Depkes RI. 2005. Anemia Gizi dan Tablet Tambah Darah untuk Wanita Usia Subur. Direktorat Jendral Bina Kesehatan Masyarakat. Direktorat Gizi Masyarakat.

Green, C.J., dan Judith, M.W. (2012). Rencana Asuhan Keperawatan Maternal dan Bayi Baru Lahir. Jakarta: EGC.

Hidayat, A.A. 2008. Riset Keperawatan dan Teknik Penulisan Ilmiah. Jakarta: Salemba Medika.

http://www.depkes.go.id, diakses pada tanggal 18 September 2016 pukul 17.15 WIB.

Manuaba, I. A. 2010. Ilmu Kebidanan, Penyakit Kandungan, dan KB untuk Pendidikan Bidan. Edisi: 2. Jakarta: EGC

Nursalam. 2013. Metodologi Penelitian Ilmu Keperawatan: Pendekatan Praktis. Edisi 3. Jakarta: Salamba Medika.

Rukiyah, dkk. (2009). Asuhan Kebidanan I (Kehamilan). CV.Trans Info Media. Jakarta.

Simkin, P., Whalley, J., \& Keppler, A. 2007. Kehamilan, Melahirkan, \& Bayi. Jakarta: Arcan. Syafrudin, \& Hamidah. 2009. Kebidanan Komunitas. Jakarta: EGC.

Walsh, L. V. (2007). Buku Ajar Kebidanan Komunitas. Jakarta: EGC.

\section{LAMPIRAN}

Tabel 1 Data Umum Kadar Hemoglobin ( $\mathrm{Hb}$ ) Pada Ibu Hamil Pre dan Post Pemberian Tablet Zat Besi (Fe) di UPTD Puskesmas Sananwetan Kota Blitar, April ( $\mathrm{n}=31)$

\begin{tabular}{|c|c|c|c|}
\hline No. & Karakteristik & Frekuensi & Prosentase \\
\hline \multirow[t]{4}{*}{1.} & Usia & & \\
\hline & a. $<20$ tahun & 2 & $6.5 \%$ \\
\hline & $\begin{array}{l}\text { b. } 20-35 \text { tahun } \\
\text { c. }>35 \text { tahun }\end{array}$ & 25 & $80.6 \%$ \\
\hline & & 4 & $12.9 \%$ \\
\hline
\end{tabular}

2. Pendidikan
a. Tidak sekolah
0
$0 \%$
b. SD
c. SMP
1
$3.2 \%$ 
No.

e. Diploma / Sarjana

\section{Frekuensi}

10

12

8

3. Pekerjaan
a. Ibu rumah tangga
b. PNS
c. Swasta
d. Pedagang

15

5

8

3

4. Tempat tinggal

a. Dataran rendah

b. Dataran tinggi

$100 \%$

5. Frekuensi Makan sehari
a. < 3 kali
0
$0 \%$
b. $3-4$ kali
c. > 3 kali
$100 \%$
0
$0 \%$

6. Makan menggunakan nasi
a. Ya 31
$100 \%$
b. Tidak

7. Penggunaan lauk dalam sehari
a. Selalu 3
$9.7 \%$
b. Kadang-kadang
c. Tidak Pernah

8 Penggunaan sayur dalam sehari
a. Selalu
16
$51.6 \%$
b. Kadang-kadang
c. Tidak Pernah

9. Penggunaan buah dalam sehari
a. Selalu
4
$12.9 \%$
b. Kadang-kadang
c. Tidak Pernah

10. Konsumsi Susu
a. Ya
b. Tidak 
No.

Karakteristik

Frekuensi

Prosentase

11. Waktu konsumsi Fe
a. Sebelum makan
b. Sesudah makan
c. Lain-lain

0

20

$0 \%$

11

$64.5 \%$

$35.5 \%$

12. Frek. Konsumsi tablet $\mathrm{Fe}$
a. Sekali sehari
b. Sekali seminggu
c. Lain-lain

31

0

0

$100 \%$

$0 \%$

$0 \%$

13. Air yang digunakan

a. Air putih

b. Tea

c. Susu
$100 \%$

$0 \%$

$0 \%$

Tabel 2 Data kadar hemoglobin $(\mathrm{Hb})$ ibu hamil pre pemberian tablet zat besi $(\mathrm{Fe}) \mathrm{di}$ UPTD Puskesmas Kecamatan Sananwetan, April $(\mathrm{n}=31)$

NO. KATEgORI FREKUENSI PROSENTASE

\begin{tabular}{l|lcc}
\hline 1. & Normal & 8 & (\%) \\
2. & Tidak & 23 & $25.8 \%$ \\
& Normal & & $74.2 \%$ \\
\multicolumn{1}{r|}{ TOTAL } & 31 & $100 \%$
\end{tabular}

Tabel 3 Data kadar hemoglobin ( $\mathrm{Hb})$ ibu hamil post pemberian tablet zat besi (Fe) di UPTD Puskesmas Kecamatan Sananwetan, April $(\mathrm{n}=31)$

\begin{tabular}{c|lcc} 
NO. & KATEGORI & FREKUENSI & PROSENTASE (\%) \\
\hline 1. & Normal & 24 & $77.4 \%$ \\
2. & Tidak Normal & 7 & $22.6 \%$ \\
\multicolumn{2}{l}{ TOTAL } & 31 & $100 \%$
\end{tabular}

Tabel 4 Data perubahan kadar hemoglobin $(\mathrm{Hb})$ ibu hamil pre dan post pemberian tablet zat besi (Fe) di UPTD Puskesmas Kecamatan Sananwetan, April $(\mathrm{n}=31)$

\begin{tabular}{c|lcc} 
NO. & KATEGORI & FREKUENSI & PROSENTASE (\%) \\
\hline 1. & Naik & 27 & $87.1 \%$ \\
2. & Turun & 4 & $12.9 \%$ \\
& TOTAL & 31 & $100 \%$
\end{tabular}


Tabel 5 Data perubahan kategori kadar hemoglobin $(\mathrm{Hb})$ ibu hamil pre dan post pemberian tablet zat besi (Fe) di UPTD Puskesmas Kecamatan Sananwetan, April ( $\mathrm{n}=31)$

\begin{tabular}{l|llcr}
\multicolumn{1}{c}{ NO } & \multicolumn{2}{c}{ KATEGORI } & FREKUENSI & PROSENTAS \\
\cline { 2 - 3 } & Pre & Post & & \\
1. & Tdk Normal & Normal & 17 & $54.8 \%$ \\
2. & Tdk Normal & Tdk Normal & 6 & $19.4 \%$ \\
3. & Normal & Normal & 7 & $22.6 \%$ \\
4. & Normal & Tdk Normal & 1 & $3.2 \%$ \\
\multicolumn{3}{|c|}{ TOTAL } & 31 & $100 \%$
\end{tabular}

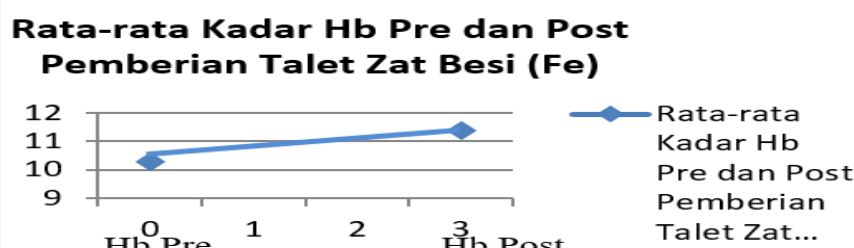

Gambar 1 Grafik rata-rata perubahan kadar hemoglobin $(\mathrm{Hb})$ ibu hamil pre dan post pemberian tablet zat besi (Fe) di UPTD Puskesmas Kecamatan Sananwetan, 